\title{
Death on Stage in the ICU: Family Facing Terminal Condition
}

\author{
Mayla Cosmo Monteiro ${ }^{1}$ \\ Andrea Seixas Magalhães \\ Rebeca Nonato Machado \\ Pontifícia Universidade Católica do Rio de Janeiro, Rio de Janeiro, RJ, Brazil
}

\begin{abstract}
The present study is part of a broader investigation with the purpose of investigating the repercussions of terminal conditions on the families of gravely ill patients hospitalized in Intensive Care Units (ICUs). The study used a qualitative clinical research methodology. Six family members of terminal patients admitted to the ICU of a medium-sized private hospital were interviewed. Five categories emerged from the analysis of the content of the interviews: perception of the illness and clinical progress; impact of admission to intensive care units; perception of the terminal condition; decision-making process; and relationship with the medical staff. This paper will present the first three categories, aiming to discuss the family members' perceptions and their emotional resources in the face of a terminal condition. Evidence shows that the imminent death of the patient generates great distress and suffering for relatives, causing intense experiences of helplessness. Family members used anticipatory mourning as a coping mechanism, allowing them to reassess their resources. Relatives also demonstrated resilient behavior, which was facilitated by social and familial support; the quality of the family-patient bond; the perception that the patient is not suffering; and the presence of religion or spirituality.
\end{abstract}

Keywords: Intensive Care Unit, family, terminal condition.

\section{A Morte em Cena na UTI: A Família Diante da Terminalidade}

\section{Resumo}

O presente estudo é parte de investigação mais ampla sobre as repercussões da terminalidade para os familiares de pacientes gravemente enfermos em Unidade de Terapia Intensiva (UTI). Utilizou-se metodologia clínico-qualitativa de pesquisa. Foram entrevistados seis familiares de pacientes em situação de terminalidade em UTI de um hospital privado de médio porte. Da análise do conteúdo das entrevistas, emergiram cinco categorias: percepção sobre a doença e a evolução clínica; impacto da internação em terapia intensiva; percepções sobre a terminalidade; processo de tomada de decisão; e relação com a equipe médica. Neste trabalho, serão apresentadas as três primeiras categorias, com o objetivo específico de discutir percepções e recursos emocionais dos familiares diante da terminalidade. Constatou-se que a morte iminente do paciente promove grande angústia e sofrimento para os familiares, provocando intensas vivências de desamparo. O luto antecipatório foi um recurso adaptativo utilizado pelos membros da família, permitindo assim que reorganizassem seus recursos. Foi evidenciado também um comportamento resiliente entre os familiares, facilitado pelo suporte social e familiar, pela qualidade do

Mailing address: Pontifícia Universidade Católica do Rio de Janeiro, Departamento de Psicologia, Rua Marques de São Vicente, 225, sala 201L, Gávea, Rio de Janeiro, RJ, Brazil 22451-900. Phone: (21) 3527-1185/35271186. E-mail: mayla.cosmo@uol.com.br 
vínculo familiar-paciente, pela percepção de que o doente não está sofrendo e pela presença da religião ou da espiritualidade.

Palavras-chave: Unidade de terapia intensiva, família, terminalidade.

\section{La Muerte en Escena: La Familia Ante una Situación Terminal}

\section{Resumen}

Este estudio forma parte de investigación más amplia sobre las repercusiones de una situación terminal para los familiares de pacientes gravemente enfermos en Unidad de Cuidados Intensivos (UCI). Se utilizó metodología clínico-cualitativa de investigación. Fueron entrevistados seis familiares de pacientes en situación terminal en UCI de un hospital privado de porte medio. Del análisis del contenido de las entrevistas emergieron cinco categorías: percepción sobre la enfermedad y la evolución clínica; impacto de la internación en cuidados intensivos; percepción sobre la situación terminal; proceso de toma de decisión; y relación con el equipo médico. En este trabajo serán presentadas las tres primeras categorías, con el propósito de discutir las percepciones y los recursos emocionales de la familia ante la enfermedad terminal. Se constató que la muerte eminente del paciente promueve gran angustia y sufrimiento para los familiares, provocando vivencias intensas de desamparo. El luto anticipatorio fue un recurso adaptativo utilizado por los familiares, permitiendo así que reorganizaran sus recursos. Fue evidenciado un comportamiento infatigable entre los familiares, facilitado por el soporte social y familiar, por la calidad del vínculo familiar-paciente, por la percepción de que el enfermo no está sufriendo y por la presencia de la religión o de la espiritualidad.

Palabras clave: Unidad de cuidados intensivos, familia, situación terminal.

Intensive Care Units (ICUs) are intended to provide medical care to grave or life-threatened patients who require around-the-clock medical or nursing assistance and constant monitoring (Alcantara, Sant'anna, \& Souza, 2013). The complexity of activities and procedures involved in this environment (the gravity of the illness, the necessity of intubation or tracheostomy, the need for punctures, for enteral nutrition, etc.) unleashes stressful, anxiety-inducing situations for both the patient and his/her family, such as the following: the impersonal nature of the environment; loneliness and isolation, facilitated by visiting-hour restrictions; uncertain or unfavorable prognostics; the lack of adequate information; the fear of death or of physical or mental suffering; and the lack of privacy and individuality (Cosmo, Morsch, Goiabeira, Genaro, \& Aragão, 2014).

In ICUs, unexpected deaths resulting from illnesses that are acute or are followed by the worsening of an underlying condition occur frequently, causing imbalance in the family system, accompanied by the perception of discontinuity of one's life history and by sensations of impotence, fragility and vulnerability. Additionally, the deaths in these units are always complex processes, with a great risk of producing dysthanasia (therapeutic futility), which is characterized by the maintenance of invasive treatments in patients with no possibility of recovery, subjecting them to a process of slow, painful death (Santana, Rigueira, \& Dutra, 2010).

Facing the terminal condition of a loved one, the family deals with moments that are hard to support psychologically. Walsh and McGoldrick (1998) emphasize that achieving balance in this process is the most difficult task to be accomplished. Death or the threat of loss has a disturbing impact on the functional equilibrium; the intensity of the emotional reaction is related to the family's degree of emotional integration at the time of the loss and to the functional importance of the family member lost. A more integrated family can react emotionally in a more direct manner at that moment, yet adapt itself 
rapidly; in contrast, a less integrated family can demonstrate a limited immediate reaction, yet later respond with physical or emotional problems (Bowen, 1998; Franco, 2008).

John Rolland (1995), the heir of medical family therapy (a specialty whose aim is to understand the relationships between somatic illnesses, family patterns and psychosocial factors), discusses the progression of chronic illnesses within a developmental context, based on the intersection of three evolutionary cycles: the lifecycles of the disease, of the individual and of the family. He proposes a Psychosocial Typology of the chronic or life-threatening disease, which is conceived based on four aspects: the onset, course, consequences and degree of incapacitation of the infirmity. This description is quite useful for the healthcare staff, for it helps to understand the impact and the adaptations the family needs to make when facing a disease.

With respect to the onset, the illness can be acute, such as a cerebrovascular accident (CVA stroke), or gradual, such as a chronic obstructive pulmonary disease (COPD). In the former case, there is a need for quicker affective and instrumental mobilization in order to manage such an adversity. In the latter (situations involving diseases with a gradual onset that become chronic), the adjustment period is prolonged and the tension is continuous, occasioning emotional distress and leading to feelings of guilt and inadequacy (Pereira \& Dias, 2007).

Regarding the course, diseases assume three forms: progressive, constant and recurrent or episodic. In the case of progressive diseases, such as cancer, the symptoms are frequent and they grow in severity. As to disease with a constant course, such as acute myocardial infarction (AMI), there is an acute moment followed by stabilization. The patient encounters a semi-permanent change that is stable and foreseeable for a while. When the disease's course is recurrent or episodic, such as asthma and ulcerative colitis, there is an alternation between periods of total or partial remission of the symptoms and periods of exacerbation. It is possible to maintain a normal routine, but there always is the threat of recurrence. When the need to hospitalize the sick family member during several of these phases arises, it is up to the family to adapt itself to the routine of the hospital, which has quite peculiar norms and rules (Santos, 2013).

Concerning the consequences, diseases can be fatal or not fatal. With respect to non-fatal diseases, there is no threat as to the duration of the patient's life. In the case of fatal diseases, which include infirmities that shorten lives (such as cystic fibrosis) and illnesses involving the possibility of sudden death (such as hemophilia or the recurrence of AMI), the patient fears being unable to execute his life plan and the family fears surviving alone in the future; in both cases, there is a tendency toward depression and anticipatory separation. The families often become stuck between a desire for intimacy and an impulse to distance themselves emotionally from the sick person. The prospect of future loss can cause difficulties in relation to maintaining the perspective of familial stability. The climate of constant apprehension and the imminence of death exacerbate the state of stress and tension (Ferreira \& Mendes, 2013). Persson, Ostlund, Wennman-Larsen, Wengstrom and Gustavsson (2008) conducted a study on life quality in terminal patients with lung cancer, and discovered that, soon after the diagnosis, the functioning of the family - cohesion, support and communication between family members - was compatible with that of the population in general. However, with the progression of the disease, such functioning began deteriorating, mainly close to death and up to six months after its occurrence.

Finally, regarding incapacitation, it can be cognitive, sensorial, kinesthetic or even social (as in the case of severe burns that are cosmetically incapacitating, leading to a decrease in the patent's capacity for social interaction). The different types of incapacitation imply differences in the necessary adaptations of the families, as occurs with cognitive incapacitation, which requires greater adjustments than when this function remains intact. The presence or absence of any significant incapacitation is what constitutes the principal dividing line relevant to construct- 
ing a psychosocial typology of the disease (Rolland, 1995).

Furthermore, when the onset of a disease coincides with a transition in the life cycle of the individual or family, issues related to prior losses are intensified. From the systemic standpoint, it is important to know the phase of the familial life cycle and the stage of individual development of all of the family members, not only of the ill member. The capacity of each family member to adapt and the speed with which such adaptation occurs are directly related to the stage of development of each individual and to each individual's role in the family. If the ill member is considered the protector and mainstay of the family, the family can feel abandoned and present difficulties in the reorganization and redistribution of roles (Rolland, 1995).

In a study on families facing the imminence of death in ICUs, Ferreira and Mendes (2013) point out that, when the families receive information concerning the gravity of the condition of their loved one, they generally experience a whirlwind of feelings, that is, a combination of shock, uncertainty, sadness, confusion, stress, anxiety and discomfort. Frequently, they do not understand what is happening to their fellow member; they do not know who to ask about it or how they should behave, leading to fear and helplessness. In such cases, grief can set in as of being informed of the diagnosis (Fonseca, 2004).

Grief refers to the breaking of meaningful ties, and it is related to the degree of affective investment made by the grieving person. The greater the ties, the greater the energy needed to break them in the case of a loss (Parkes, 2009). The experience of having a gravely ill family member admitted to an ICU can activate a coping mechanism in the members of the family, a mechanism known as anticipatory grief, by which it is possible to prepare oneself, cognitively and emotionally, for imminent death, generating intense suffering. Research on anticipatory mourning becomes indispensable with respect to working with family members that go through long hospitalization periods. Between the discovery of the diagnosis and the death itself of the family member/patient, the most common losses are the following: loss of one's health, separa- tion from one's habitual daily routine due to hospitalization, and loss of one's sense of control and security (Cardoso \& Santos, 2013; Fonseca, 2004; Rando, 2000). When the inevitability of death is announced, it dominates family life, with a prevalence of issues that involve separation, sadness, resolution of the grief, and postmourning family life. The families must therefore manage various demands at the terminal moment of their loved one (Gonzaga \& Peres, 2012; Pereira \& Dias, 2007; Schmidt, Gabarra, $\&$ Gonçalves, 2011).

In this manner, caring for the families is one of the most important parts of the global care of hospitalized patients, principally because the patients are generally sedated and thus prevented from making decisions (Moritz et al., 2011; Probst, Gustin, Goodman, Lorenz, \& WellsDi Gregorio, 2016). Within the scope of such considerations, in this research we sought to discuss the perceptions and emotional resources of family members facing a terminal condition.

\section{Method}

Ample research was conducted with the aim of investigating the repercussions of the terminal condition for the relatives of gravely ill patients in ICUs. We used a qualitative clinical methodology, which corresponds to a series of scientific methods, techniques and procedures appropriate to describing and interpreting the meanings and significance given to various phenomena belonging to the field of the healthillness binomial, which are related to the team of professionals, the patients and the family members (Turato, 2008).

Six members of the families of patients in a terminal situation in the ICU of a mid-sized private hospital participated in this study. In relation to the ill person, the criterion for inclusion was the fact of being hospitalized in an ICU for over 48 hours due to a grave underlying disease in an advanced stage. In relation to the patient's family, the criteria were the following: being the family member responsible for the patient and identified by the multi-professional team as the family's caregiver, and having been chosen by the unit's psychology department. 
Table 1

Family Members of Patients in Terminal Situations

\begin{tabular}{cccc}
\hline $\begin{array}{c}\text { Identification of } \\
\text { family member }\end{array}$ & Relationship & Patient data & $\begin{array}{c}\text { Time in the } \\
\text { ICU }\end{array}$ \\
\hline Ana, age 70 & Daughter & Alice, age 93, widow, ischemic stroke & 45 days \\
Beatriz, age 65 & Wife & Bernardo, age 79, cancer with multiple metastases & 5 days \\
Cristina, age 78 & Mother & Carlos, age 40, advanced lung cancer & 10 days \\
Denis, age 63 & Husband & Denise, age 63, advanced hepatic cirrhosis & 88 days \\
Elisa, age 79 & Wife & Edson, age 84, advanced COPD and cachexia & 173 days \\
Francisco, age 55 & Son & Filomena, age 83, advanced hepatic cirrhosis & 61 days \\
\hline
\end{tabular}

Interviews were conducted based on a semistructured script, encompassing the following topics: perception as to the disease and the clinical progress; preexisting relationship with the patient and her/his status in the family; perception concerning communication with the medical staff; factors valued in the decisionmaking process; and conceptions regarding death and dying.

Contact with the participants was facilitated due to the twofold participation of the first author, both as the institution's clinical psychologist and as a researcher. All of the interviewed family members were monitored by the psychologist-researcher, a fundamental condition for their participation in the study due to the importance of establishing rapport within the context under study, considering the sensitivity and delicateness required by the moment. The invitation was made only after the medical staff informed the family about the aggravation of the patient's clinical condition and the imminence of death. The interviews were conducted in the office of the hospital's Psychology Department and were scheduled one day in advance. We also made use of several data obtained from the psychological consultations conducted with family members, especially those relating to familial functioning. Ethical norms were observed (signing of the Informed Consent form and approval by the Research Ethics Committee). The names used here are fictitious.
The content analysis method proposed by Bardin (2011) was used to analyze the data collected during the interviews. Based on the data collected, five categories of analysis emerged: perceptions concerning the disease and clinical progress; the impact of hospitalization in an ICU; perceptions regarding the terminal condition; the decision-making process; and the relationship with the medical staff. In order to achieve the objectives of this study, we will discuss the first three categories. The remaining categories were discussed in other published works.

\section{Results and Discussion}

In relation to the patients, the period of hospitalization in the ICU was relatively diversified, varying between 5 and 173 days. As to the amount of time spent in a terminal condition, the facts are as follows: rapid death, between 5 and 10 days (Bernardo and Carlos); prolonged death, over 50 days (Denise, Edson and Filomena); and delayed, uncertain death, for the patient exhibited an improvement in her condition and was released from the ICU (Alice).

Corroborating the data obtained in the literature (Cosmo et al., 2014; Moritz, Rossini, \& Deicas, 2012), elderly persons in a terminal state were the majority in the present study. The average age of ICU patients has been rising in recent years, due to the increasing lifespan of the population and to better control of chronic 
degenerative diseases. Additionally, the family members that we interviewed are also mostly aged, that is, seniors taking care of seniors. One of the characteristics of ageing is the progressive loss of health, combined with other losses - youthfulness, functional and occupational capacity, family members and friends, among others. This scenario justifies the concern over the care given to the elderly, regardless of whether they are patients or relatives, especially when death is approaching (Cosmo et al., 2014). Therefore, within the ICU context, the family, in addition to being the patient's caregiver, must also be a recipient of the medical staff's care (Kappaun \& Gomez, 2013; Schmidt et al., 2011).

\section{Perception about the Disease and Clinical Progress}

The family members' perception with respect to the disease is related to its typological and psychosocial aspects, as described by Rolland (1995).

Mom had a stroke right out of the blue. She was always healthy; of course, she's older than 90 and always has a little problem here or there, but nothing very serious. . . And just to think that she went to the fruit and vegetable store to buy vegetables to make a stew when all of this happened. She fell onto the floor, fainted, and completely wet herself. . . . Now she's the way she is, with a tube and sedated. (Ana, daughter, age 70) Yesterday, the doctor said he was in a really bad state, that he would have go on the tube, but I didn't realize he could die; it was a shock. I thought he had a chance of recovering; he was really strong and loved life. He loved singing and playing the guitar. I never thought this could happen to him, precisely he who always took good care of himself. He discovered the cancer a little over a year ago and always believed he would be cured. Initially, he didn't want to do chemotherapy; I think it was because he was afraid of the side effects. It was a shock to everybody; he didn't smoke and was really disciplined with his eating habits. He ran, too, participating in various marathons [pause, sobs]. (Cristina, mother, age 78)

Acute diseases appear abruptly within the familial context and require rapid adaptation on the part of the family members (Rolland, 1995). In Ana's account, we see how the disease caught her by surprise, for it was unexpected, despite her mother's advanced age. This crisis phase includes an initial period of adaptation and management, and involves practical issues such as learning to cope with the hospital environment, with the therapeutic procedures (sedation and orotracheal intubation) and with the healthcare staff (Caiuby \& Andreoli, 2005).

In contrast to Ana, Cristina already knew about her son's diagnosis (lung cancer), but she had to cope with an abrupt worsening of his clinical condition. She demonstrated surprise in relation to his clinical progress and, since she considered that her son was young, an athlete, disciplined as to his health and a nonsmoker, she believed he could avoid his death. We hypothesize that she was going through the phase of negation, with the presence of shock and disbelief, which are common when a family member is facing a grave, life-threatening disease (Fonseca, 2004).

We highlight the traumatic experience within this crisis context, precipitated by the diagnosis and clinical deterioration. According to Meyer (2007), the notion of crisis covers an expansive terrain with various access routes: the aggravation of a conflict, the rupture of equilibrium, the intensification of a situation of tension, a difficult or dangerous moment of a process, and disorder accompanied by the search for a solution. Freud (1926/2014) referred to trauma as a state of psychic abandonment, a situation of impotence that is actually experienced. Trauma is a precipitant stimulus that initiates the illness chain; the traumatic state results from the absence of relatively successful defenses. The dimension of the surprise, of the shock and of the unexpected, which are present in the trauma, promotes great anguish and suffering, an experience associated with a subjective sensation of abandonment, which was felt by some of the people interviewed. 
In contrast, Beatriz narrates the progression of her husband's illness, which was advancing insidiously and revealing itself in incremental steps:

He would sometimes say, when he was in bed, that he had a lot of stomach pains and that they were gases. We used to go to the movies every weekend, and he even gave up going because he said he felt bad due to the gases.... Until he finally accepted going to the doctor and we discovered that he had to undergo oncological surgery; that his intestine would have to be cut, yet in a spot in which its functions would be preserved. But the doctor said he also had two small spots on his liver and that he would have to have an ablation. That was in June 2012. And the doctors said he would have to be monitored by an oncologist, who ordered a tomography and noticed various small spots, and then chemotherapy began. He lost a lot of weight, 10 kilos in all. . . . He underwent magnetic resonance imaging; the doctor didn't tell us, but we can read, and there I saw that the medical term for a lesion is metastatic cancer. Last week, we went for a checkup, and the doctor gave him something called codeine [an opium-derived analgesic used to alleviate mild pain]; and I began to perceive that he became disoriented, and I soon associated that with the medication. He kept sitting and standing up all night long. Then, early in the morning, I phoned the doctor, and she told me to reduce the dosage and increase the interval. She said, "he's got... that disease... the thing you were always so worried about has occurred". (Beatriz, wife, age 65)

The chronic stage of Bernardo's disease was marked by physical, social and functional limitations, requiring constant adaptation and adjustment to the new conditions that were gradually presented (intestinal surgery, chemotherapy, small spots in the liver, interruption of the treatment). Whether through the doctor's difficulty in explaining the disease and its prognosis or through Beatriz's difficulty in being more objective and direct in her inquiries, and even in per- mitting the patient to participate more actively in his treatment, the fact is that they both faced the gravity of the situation shortly before Bernardo's death.

Another family's member also refers to the progressive losses and incapacitation occasioned by a chronic disease:

He began to be ill two years ago, but in the last nine months he got worse, until reaching the present point. He no longer wanted to walk, talk; eating was a sacrifice. So much so that he arrived here dehydrated and undernourished. He was losing his strength; and he began isolating himself, very sad. . . until he reached the point of having to be hospitalized. During these months, we have all struggled, together with him, always giving him support and affection. He used to be very proud, strong, always walking erectly. Seeing him waste away like this, walking hunched over, spitting secretion in a cup, hurt me. (Elisa, wife, age 79)

For a while, the patient (Edson) was able to keep himself stable, and it was still possible to maintain normality despite the "abnormal" presence of the disease (COPD). However, its progression was inevitable and it affected the patient on all functional levels, making it irreversible. The chronic stage can be long or short, depending on the disease's evolution, and it involves periods alternating between stability and instability of the clinical condition and uncertainty as to future functioning, thus requiring new forms of coping, changes in the self-definitions of the patient and the family due to the various losses suffered, and long periods of adaptation (Pereira \& Smith, 2005).

The Hepatitis $C$ began 37 years ago, when mom went to have surgery, but, as they say, it's silent. Mom always spoke of it, but we thought she was stronger and that the disease would never take hold of her. She loved living, traveling, going out with her friends, being with us and with the grandchildren. She didn't seem ill. This time, she was arriving from an international trip when she began to feel ill. And we brought her here. The physicians performed 
surgery, but it was unsuccessful ... In the last few days, before coming here, she was bleeding all over. The blood was escaping through her mouth and through the feces. (Francisco, son, age 55)

As can be seen in the above account, depending on the patient's personality, life story, familial background and beliefs, resilience can emerge as a form of coping with this period. "Resilience" refers to an individual's capacity to be reborn from the adversity, strengthened and with more resources; it is made up of an active process of resistance, reorganization and growth in response to the crisis and the challenge (Walsh, 2005).

\section{Impact of Hospitalization in the ICU}

Despite the implantation of humanization programs in ICUs, intensive care still reminds one of suffering, death and a lack of humanism. The development of modern technology and pharmacology applied to medical science made it possible to cure or stabilize various diseases, but, at the same time, it generated increasingly automated structures and professional practices considered cold and distant from patients and their families (Quintana, Kegler, Santos, \& Lima, 2006).

The interphone rings and a voice answers,

"he's in surgery, come back in a while". What is this? There needs to be someone inside there who opens the door and looks me in the eye. During all these months of going back and forth to and from the hospital, I've seen dozens of people outside with tears in their eyes, talking on the interphone and then leaving. You know, they need have someone to open the door and explain what's going on. That calms us down. (Denis, husband, age 63)

Family members often have the expectation of getting "inside the ICU." They anxiously wait "outside" for visiting hours (limited to two hours a day at the hospital) to begin. In the case of this family member (Denis), he remained at the hospital from 8 am to 10 pm every day. What is also noticeable is the discomfort caused by the interphone, a technological device used to control people's access to the unit with the intention of avoiding harm to the patient. On the other hand, at another moment in the interview, he refers to the ICU's technology as saving his wife's life:

$D$. arrived here in a grave state, bleeding heavily, and if were not for the ICU's equipment, she would have departed already; she would have passed away already (Denis, husband, age 63).

Such ambivalence with respect to the technology available in the ICU is also evidenced in another account:

When we arrive here and find her sedated, with the tube, our hearts ache, you know what I mean? All of those devices connected to her frighten me, and the huge amount of medications she has to take to stay alive scares me because they're really strong medications. It's unbelievable, but if it weren't for these devices, she wouldn't have gotten this far. (Ana, daughter, age 70)

Within the ICU context, medical care is still guided by the biomedical model, centered on the pathology and on technical procedures, to the detriment of the feelings and fears of the patient and his/her family and the manner in which they experience the health-illness situation (Moritz, 2007). Duarte (2003) comments that ICUs seem to represent the most acute form of the patientillness dichotomization, by subjecting their users to circumstances and conditions frequently experienced or represented as inhuman or depersonalizing.

The Brazilian Association of Intensive Medicine (AMIB, in Portuguese) advocates that the humanization of ICUs signifies caring for the patient as a whole, with consideration of the familial and social context, and embracing measures to make the physical environment of such units more welcoming and less impersonal (Souza, 2010). Nonetheless, the ICU's physical structure itself and its functioning contribute to separate the family from the care given to the patient, for, in addition to the limitation on visiting hours, there are no seats or armchairs to accommodate the family. Moreover, the ICU has its own specific routine that often disregards the family's needs. 
ICUs operate on the basis of protocols, yet life is malleable; things are malleable. There's a lack of wisdom, of flexibility. Preparedness is lacking. It seems like they're doing you a favor. The ICU takes hold of the patient, and the patient ends up being their property; you can't visit the patient when you want to. If my wife were not important to me, I wouldn't be the way I am today [sobs]. I'm really worn out because every time it's 3 pm or 8 pm [visiting hours], I don't know if I'll see my wife, because there's always some obstacle. I understand that there are times when serious complications occur, and I wait. But, bath time during visiting hours? So, change the visiting hours or change the bath hours. All of this, throughout the course of four hospitalizations, is really wearing me out. There is no respect for those outside the ICU. (Denis, husband, age 63)

At the same time that they feel excluded from caring for the patient, estranged, impotent and anguished "outside," they know that their loved one is receiving advanced life support "inside" and that without it s/he would probably already be dead. It is important to point out that Denis's relationship with the staff on duty occurred in a conflicting manner during the long hospitalization of his wife in an ICU (88 days). Prolonged hospitalization, mainly in situations in which there is a high risk of death and the chances of recovery are slim, is a factor that produces stress for both the family and the medical staff, which also feels impotent. During hospitalization, caregiving family members often exhibit symptoms like depression, anxiety, sleep and eating disorders, and social and emotional isolation. Depending on the length of hospitalization, they generally give up aspects of their own lives in order to be with the patient, which can lead to everything from greater vulnerability and overburdening to a state of psychosocial chaos, accompanied by feelings of fear, guilt and anger (Barros, Andrade, \& Siqueira, 2013; Pereira \& Dias, 2007; Santos, 2013).

There also is a perception that ICUs inflict suffering on patients, by subjecting them to invasive procedures and connecting them to various devices. In our practice, we notice that there is frequently a concern on the part of a family member as to the patient's pain.

He arrived prostrated. They moved him and he must have felt pain; he became outraged, desperate, I think. And, in order to get things done, they had to tie him down. He was kept under restraint [sobs]. It was really terrible for us to see that. And he called out to me, and said, "get me out of here, get me out of here". And I told him to keep quiet so that he could get released, because I didn't even know how to untie him. Shortly after that, the doctors gave him a tranquilizer, I think, and he passed out. And it's really terrible being unable to talk to him, unable to know how he's feeling. But, just to see him with an appearance different from his aspect on monday calms me, but I don't know how long I'll have him here close to me. I really feel like I'm going to lose him [sobs]. (Beatriz, wife, age 65)

When the patient is very restless and experiencing an altered state of consciousness, $\mathrm{s}$ /he is generally "confined to the bed." This scene causes the family great distress, and it is important for the healthcare staff to emphasize that such a procedure is employed to guarantee the patient's safety, by preventing the patient from falling off the bed, by avoiding that tubes and catheters get pulled out, etc. Nevertheless, despite the suffering inflicted on patients, there is relief when they are sedated, exhibiting a "calm physiognomy," that is, when they are silenced.

Another peculiarity of ICUs is unexpected death, which occurs even after having employed every available therapy, such as in the case of trauma or septic shock (Lago, Garros, \& Piva, 2007). We thus have a traumatic situation in which the resources with which the individual functions in her/his day-to-day life were overcome by some sudden situation.

It's really hard to bear all of this; it seems like a nightmare. You sleep thinking you'll rest, but then the nightmare comes and awakens you in the middle of the night; it scares you. That's how I feel. Sometimes 
I think it's not real and that I only need a little time to recover, but then I look at him with all those contraptions and I see that it is real, very real. And each bit of news I get from the doctors leaves me more helpless [sobs]. (Cristina, mother, age 78)

Death or the threat of loss has a disturbing impact on a family's functional stability. Family members that are able to communicate with each other, share information and options, and make use of outside help seem to face such moments better (Pereira \& Dias, 2007; Prince-Paul, 2008).

I have my children, grandchildren and great-grandchildren. I keep up with my Pilates exercises and visit my grandchildren to keep myself busy. I know I can't make the visits together, for I know I'm my kids' mainstay. We're always together, taking turns on the visits so that Edson never remains alone ... The support I get is what helps me not give up. And back at home we have always conversed a lot and supported each other. We're very united; every Sunday we have lunch at home and during the week the kids always stop by to see me. Now, during all these months of hospitalization, my son has been sleeping with me, and I feel supported by him. (Elisa, wife, age 79)

... the one who always stayed with him was me. The kids only started showing up more often at the end of last year. Everything was always up to me; they could never stay with their dad; they always had some excuse. In other words, I've never had help. Yesterday, when I said I wanted to stay close to him in the ICU, the kids soon began to say, "Are you going to stay for 24 hours? Because I can't, so don't count on me". If I could, I'd take him home. As far as the kids are concerned, he'll stay in the ICU. (Beatriz, wife, age 65)

According to the literature, social and the family's support play a decisive role in terms of a family's adaptations to situations involving illness and losses (Lima, Amazonas, \& Menezes, 2012; Santos, 2013). Elisa's account demonstrates how such support is important in relation to logistic (family members taking turns on visits to the ICU) and emotional support. On the other hand, a lack of support at such moments indicates prior conflicts and can even aggravate them during hospitalization, as is evidenced by the words of Beatriz, who never could count on real help from the children of her husband's first marriage.

\section{Perceptions Regarding the Terminal State}

Sudden, afflictive contact with human finiteness is often feared and avoided and requires familial adaptation. Mourning involves several phases, with frequent torpidity among family members in ICUs (Fonseca, 2004).

Do you think God will take me in His lap if He takes my son away from me? I don't know if I still have the strength to bear this. I talk with him and tell him that he just can't do this to me, that he still has a lot of life to live, that he still needs to get married, have kids. (Cristina, mother, age 78)

"Just imagine if she dies. I'll invade that place with a war tank [sobs]. I'm not ready to lose her" (Denis, husband, age 63).

The above statements denote incredulity, despair, helplessness and fear of psychological non-survival in the face of the imminent loss of their loved ones, due to their importance in the family and to the family member's emotional dependence on the sick person. In the case of Denis, we see that the threat of losing his wife represents the emotional loss of his own self, making him more vulnerable. On the other hand, the death of a child, which is Cristina's case, is considered life's greatest tragedy by most people, with the aggravating factor of Cristina being elderly and having lost another child previously (Parkes, 2009; Schmidt et al., 2011).

In addition to the patient's significance to the family, the moment in the familial life cycle also acquires importance for the family in terms of comprehending the emotional repercussions of mortality. The death of the elderly is seen as an integral part of the familial life cycle, but it does not occur without stress.

My mom's death is part of life, but we never stop to think that it can happen, even though 
she's 93. I'm very catholic and I believe life continues in another dimension. My mom has always been a really good person; she has always done good and deserves an end without suffering. I don't want her to die soon, but I also don't want her to suffer. (Ana, daughter, age 70)

We're catholics, but my mom is a follower of spiritism. So, death is seen in a different light. She always faced death well; she had no fear of losing or dying. She lived her 83 years of life really well. . . She was fully aware that she would die soon. She said goodbye to everyone. Technology facilitated her contact with grandchildren that are far away in other cities and countries. I put them on Skype and they said goodbye to her [sobs]. She also made various recommendations, requests, and a formal distribution of her possessions. She also asked us to have her cremated and to take her urn to the south, to the small town where she was born and where her parents were buried, and my dad, too. That's it; our plans with her will have to be interrupted, because this time she didn't overcome the disease. (Francisco, son, age 55)

In the case of elderly patients, despite their awareness of the imminence of death, there is suffering, especially during hospitalization in the ICU, where the patient is subjected to various invasive procedures. Ana seems quite ambivalent: at the same time that she does not want her mother to die soon, she also does not want to see her suffer. Another important aspect relates to the patient's previous life quality and to the quality of the ties established with family members. Perceptions to the effect that the sick person lived life well, enjoyed moments together with family members and had a good relationship with them facilitate acceptance and coping. Conducting parting rituals (as described in the above account) also benefits everyone involved, bringing the family closer to this final moment and, at the same time, preparing it for the separation, as an integral part of the life process (Schmidt et al., 2011).
As mentioned above, losing a child is of the order of the unspeakable, and it leaves a void that is difficult to fill. Moreover, to many people, losing one's parents, regardless of their age, amounts to losing a secure foundation. The death of one's parents leads one to come across the final phase of one's own life cycle, making a transformation in one's identity favorable (Walsh \& McGoldrick, 1998).

In addition to the aforementioned factors, religion also contributes as a decisive factor in the mourning process. Corroborating the literature we researched, we perceived in our practice that, during our appointments with the families, religiosity and spirituality help family members face a grave illness, promoting the relief of their suffering, providing comfort and offering a meaning for it (Franqueira, Magalhães, \& FéresCarneiro, 2015; Pereira \& Dias, 2007; Schmidt et al., 2011).

But I left it up to God; be it as God wishes. You heard the doctor say that the condition is catastrophic and that I have to begin preparing myself. But, there's always a hope; nothing's impossible for God, right? (Ana, daughter, age 70)

He's my youngest child. God just can't take him away from me. When he visits me, he always arrives happy, singing and saying, "I'm arriving, my old lady" [sobs]. He's a very special son. I'm hoping for a miracle; a miracle has to occur. (Cristina, mother, age 78)

Hope for a divine solution, a miracle cure, is reinforced by the family members' faith, thus perpetuating their hope, which is considered a form of emotional support and is necessary for the family to be able to accompany the patient until the very last moments (Ferreira \& Mendes, 2013). Moreover, death or grave illness in young patients is considered something that terminates an incomplete life, off the normal course, promoting a greater rupture in the family.

Anticipatory grieving is an adaptive resource used by family members to face the imminent loss of a loved one (Fonseca, 2004; Rando, 2000). 
Everyone is shocked; no one expected this. I'm really scared, too. The doctor just told me, in the following terms, "the tomography is disastrous; if she makes it out of sedation, it'll be without interaction" [silence]. . . . Nobody's sleeping right and the days are really sad without her. ... Mom's death arrived so suddenly, without warning, that is, she hasn't died yet, but it's as if she was practically dead, you know? (Ana, daughter, age 70 )

I think they gave him a sedative and he slept. The doctor asked me to wait outside and I left with a heavy heart, because I knew it could be the last time I'd be with him without being in this situation [silence]. I really need my son; he can't depart [weeps heavily]. (Cristina, mother, age 78)

For these family members, news of the imminence of death arrived without warning, suddenly and unexpectedly. The experience of anticipating loss involves a wide range of anticipatory emotional reactions such as the anxiety of separation, existential solitude, sadness, disappointment, anger, resentment, guilt, exhaustion and despair. This process also involves several phases, such as shock, negation, ambivalence and revulsion. As was discussed earlier, at times a family member can want to be closer to the patient; at other times, she can desire distance and flight from such an unbearable situation (Fonseca, 2004; Rando, 2000).

While, on the one hand, we have the sudden, unexpected character of the terminal condition, on the other, we have a long wait and uncertainty as to the moment of death, which are propitiated by the ICU technology's interference in the death process, causing a certain destabilization in the family, for the family can prepare itself for the imminent loss and begin to detach itself from the patient. Insofar as the family is able to perceive and assimilate the fact that one of its members is in the terminal stage, it can reorganize its resources to face the imminent death of its loved one, and thus prepare itself for posthumous mourning. Nonetheless, this process does not eliminate the impact caused by the death at the exact moment in which it occurs.
I know that when we're emotionally unaffected, death is a passage and, from then on, there must be something more that we don't know because nobody ever came back to tell. I say this because I'm catholic. But when we see that the hour is arriving, it's different. Even today, I still feel my dad's death, and now I'm about to lose my second man. When I arrive at home and see all of his things, in the room we slept in these last few nights, I still haven't been able to touch anything. I only made the bed, but I've been unable to put anything out for washing. I get home, and I really miss him. You know, he was stubborn, but we were companions. (Beatriz, wife, age 65)

Beatriz narrates how difficult it has been to live life without Bernardo, even though for just a few days. Walsh and McGoldrick (1998) highlight the recognition of death as one of the crucial tasks of adaptation. In the case of Beatriz, it is harder for her to adapt because the people she could count on to share the experience of loss, her husband's children, are emotionally unavailable to do so. Another factor that causes difficulties is a history of losses of other significant people. We could say that, in such situations, the family member goes through various instances of mourning.

I just can't believe this is happening again. I lost my middle child sixteen years ago and I suffered greatly. She had had kidney problems since adolescence and received a transplant, which developed complications ... Six months ago, I lost my mom, too, when she was close to turning 90, and was sad and always tried to cheer me up. But that just doesn't compare with what I'm going through now. My mom already was pretty old; she didn't suffer; and we expect that, through life's natural order, our parents will depart before us. But the loss of a child? No, there are no words for that. And it's not only one child, you know? Two of them will leave a gap that nothing will fill [weeps] . . . Death is pain, separation and suffering. There isn't a single day that I don't think about my daughter, and I imag- 
ine I'll probably spend the rest of my life thinking about my two children now, gradually dying [weeps heavily...]. (Cristina, mother, age 78)

I've lost a lot of loved ones already; I've already suffered so much, and I still suffer, because I'm really alone. I lost my parents in an accident that I was also in, and later my uncle, who was like a father to me; then, I lost a girlfriend who was six months pregnant. Mylife only started again two years ago now. So I think it's pure stupidity not letting me stay with my wife [sobs]; she'll be leaving us soon... [weeps] let me be with her; each hour, minute, is one more hour, one more minute with her. (Denis, husband, age 63) It is fundamental to consider the families' relationships with past losses and deaths. An excess of past losses and a history of difficulty in coping with such losses seem to hinder a family's ability to cope with a present loss, making its members more vulnerable to depression, complicated mourning and post-traumatic stress disorder during the period following the death (Franco, 2008; Wiegand, Grant, Cheon, \& Gergis, 2013).

\section{Final Considerations}

Despite being an integral part of human nature, death affects each human being in a very singular manner. One's reaction to this event depends on innumerous factors: the characteristics of the individual passing away (age, role in the family, type of death); of the grieving person (personality, past history of losses, religion, and social and familial support); and of the relationship between them. Within the hospital context, the intricate web that forms between the physician, the patient and the patient's family is also considered. We observed that the terminal condition of the ICU patient is permeated by clinical, familial, social, cultural, religious and economic issues, encompassing multidimensional aspects.

The prolongation of the hospitalization period, as was the case of most of the patients, together with a high risk of death, causes imbalance in the familial system, increasing the impotence of the family's members and causing ambivalent feelings to emerge, for, at the same time that the family members do not want their loved one to die, they also do not want to see him/her suffer. We saw that, as the literature demonstrates, ICUs promote dysthanasia by prolonging the death of patients with a grave, progressive and irreversible disease.

Nonetheless, we also observed resilient behavior in the group of family members. Among the factors that facilitate accepting and coping with this difficult moment are social and familial support; the perception that the patient lived life well; the quality of the family-patient ties; a good relationship with the medical staff; the perception that the patient is not suffering, often due to being silenced by sedatives; and the presence of religion or spirituality. Such factors are also described in the literature as being important determinants in familial adaptation to situations of illness and losses. Based on these results, we thus emphasize the importance of creating areas in hospitals for listening to family caregivers, who embrace and foster the elaboration of the meanings produced by them in relation to the illness and death of their loved ones.

\section{References}

Alcantara, L., Sant'anna, J. L., \& Souza, M. G. N. (2013). Adoecimento e finitude: Considerações sobre a abordagem interdisciplinar no Centro de Tratamento Intensivo oncológico [Illness and finiteness: Considerations as to the interdisciplinary approach at the Oncological Intensive Care Center]. Ciência: Saúde Coletiva, 18(9), 25072514.

Bardin, L. (2011). Análise de conteúdo [Content analysis]. São Paulo, SP: Edições 70.

Barros, S. M. M., Andrade, M. A. C., \& Siqueira, F. A. A. (2013). Cuidar de um familiar com câncer: Contribuições da terapia familiar sistêmica [Caring for a family member with cancer: Contributions of systemic familial therapy]. Pensando Famílias, 17(2), 96-110.

Bowen, M. (1998). A reação da família à morte [The family's reaction to death]. In F. Walsh \& M. McGoldrick (Eds.), Morte na família: Sobrevivendo às perdas [Death in the family: 
Surviving the losses] (pp. 105-117). Porto Alegre, RS: ArtMed.

Caiuby, A. V. S., \& Andreoli, P. B. A. (2005). Intervenções psicológicas em situações de crise na unidade de terapia intensiva. Relato de casos [Psychological interventions in crisis situations in the ICU]. Revista Brasileira de Terapia Intensiva, 17(1), 63-67.

Cardoso, E. A. O., \& Santos, M. A. (2013). Luto antecipatório em pacientes com indicação para o transplante de células-tronco hematopoéticas [Anticipatory mourning in patients indicated for transplant of hematopoietic stem cells]. Ciência: Saúde Coletiva, 18(9), 2567-2575.

Cosmo, M., Morsch, D., Goiabeira, F., Genaro, L., \& Aragão, P. (2014). O paciente em unidade de terapia intensiva - Critérios e rotinas de atendimento psicológico [The patient in the intensive care unit - Psychological treatment criteria and routines]. In K. Kitajima, F. Saboya, J. Marca, \& M. Cosmo (Eds.), Psicologia em unidade de terapia intensiva - Critérios e rotinas de atendimento (pp 1-21). Rio de Janeiro, RJ: Revinter.

Duarte, L. F. D. (2003). Indivíduo e pessoa na experiência da saúde e da doença [The individual and person undergoing the experience of health and illness]. Ciência: Saúde Coletiva, 8(1), 173183.

Ferreira, P. D., \& Mendes, T. N. (2013). Família em UTI: Importância do suporte psicológico diante da iminência de morte [Families in ICUs: The importance of psychological support in the face of the imminence of death]. Revista $S B P H$, 16(1), 88-112.

Fonseca, J. P. F. (2004). Luto antecipatório [Anticipatory mourning]. Campinas, SP: Livro Pleno.

Franco, M. H. P. (2008). Trabalho com pessoas enlutadas [Working with persons in mourning]. In V. A. Carvalho, M. H. P. Franco, M. J. Kovàcs, R. P. Liberato, R. C. Macieira, M. T. Veit, ...L. H. C. Barros (Eds.), Temas em psico-oncologia [Themes on psycho-oncology] (pp. 398-402). São Paulo, SP: Summus.

Franqueira, A. M. R., Magalhães, A. S., \& Féres-Carneiro, T. (2015). O luto pelo filho adulto sob a ótica das mães [Grieving for an adult child from a mother's perspective]. Estudos de Psicologia (Campinas), 32(3), 487-497.

Freud, S. (2014). Inibição, sintoma e angústia [Inhibition, symptom and anguish]. In Obras Com- pletas: Vol. XVII. São Paulo, SP: Companhia das Letras. (Original work published 1926)

Gonzaga, L. Z. M., \& Peres, R. S. (2012). Entre o rompimento concreto e a manutenção simbólica do vínculo: Particularidades do luto de cuidadores familiares de portadores de doenças crônico-degenerativas [Between the concrete severance and the symbolic maintenance of the bond: Particularities of family caregivers' mourning for patients with chronic degenerative diseases]. Vinculo, 9(1), 10-17.

Kappaun, N. R. C., \& Gomez, C. M. (2013). O trabalho de cuidar de pacientes terminais com câncer [Caring for terminal cancer patients]. Ciência: Saúde Coletiva, 18(9), 2549-2557.

Lago, P. M., Garros, D., \& Piva, J. P. (2007). Terminalidade e condutas de final de vida em Unidades de Terapia Intensiva Pediátrica [Terminal diseases and conduct at the end of life in Pediatric Intensive Care Units]. Revista Brasileira de Terapia Intensiva, 19(3), 359-363.

Lima, F. A., Amazonas, M. C. L. A., \& Menezes, W. N. (2012). Estratégias de enfrentamiento (coping) de hijos que tienen la madre o el padre internado en una Unidad de Terapia Intensiva (UTI) [Coping strategies for children whose mother or father is hospitalized in an Intensive Care Unit]. Diversitas: Perspectivas en Psicología, 8(1), 151-164.

Meyer, L. (2007). Trauma familiar e crise [Family trauma and crisis]. Jornal de Psicanálise, 40(72), 165-175.

Moritz, R. D. (2007). Como melhorar a comunicação e prevenir conflitos nas situações de terminalidade na Unidade de Terapia Intensiva [How to improve communication and prevent conflicts in terminal situations in Intensive Care Units]. Revista Brasileira de Terapia Intensiva, 9(14), 485-489.

Moritz, R. D., Deicas, A., Capalbo, M., Forte, D. N., Kretzer, L. P., Lago, P., ...Ropelato, R. (2011). II Fórum do "Grupo de Estudos do Fim da Vida do Cone Sul": Definições, recomendações e ações integradas para cuidados paliativos na unidade de terapia intensiva de adultos e pediátrica $\left[2^{\text {nd }}\right.$ Forum of the "Southern Cone End-of-Life Studies Group": Definitions, recommendations and integrated actions for palliative care in adult and pediatric intensive care units]. Revista Brasileira de Terapia Intensiva, 23(1), 24-29. 
Moritz, R. D., Rossini, J. P., \& Deicas, A. (2012) Cuidados paliativos na UTI: Definições e aspectos éticos-legais [Palliative care in ICUs: Definitions and legal-ethical aspects]. In R. D. Moritz (Ed.), Cuidados paliativos nas unidades de terapia intensiva (pp. 19-31). São Paulo, SP: Atheneu.

Parkes, C. M. (2009). Amor e perda: As raizes do luto e suas complicações [Love and loss: The roots of mourning and its complications]. São Paulo, SP: Summus.

Pereira, L. L., \& Dias, A. C. G. (2007). O familiar cuidador do paciente terminal: $O$ processo de despedida no contexto hospitalar [The terminal patient's family caregiver: The parting process in the hospital context]. Psico, 38(1), 55-65.

Pereira, M. G., \& Smith, T. E. (2005). Biopsychological model in the practice of family therapy. International Journal of Clinical Health Psychology, 6(2), 455-467.

Persson, C., Ostlund, V., Wennman-Larsen, A., Wenagstrom, Y., \& Gustavsson, P. (2008). Health-related quality of life in significant others of patients dying from lung cancer. Palliative Medicine, 22, 239-247.

Prince-Paul, M. (2008). Understanding the meaning of social well-being at the end of life. Oncology Nursing Forum, 35, 365-371.

Probst, D. R., Gustin, J. L., Goodman, L. F., Lorenz, A., \& Wells-Di Gregorio, S. M. (2016). ICU versus non-ICU hospital death: Family member complicated grief, Posttraumatic Stress, and Depressive Symptoms. Journal of Palliative Medicine, 19(4), 387-393.

Quintana, A. M., Kegler, P., Santos, M. S., \& Lima, L. D. (2006). Sentimentos e percepções da equipe de saúde frente ao paciente terminal [Feelings and perceptions of the healthcare staff dealing with a terminal patient]. Paidéia (Ribeirão Preto), 16(35), 415-425. doi:10.1590/S0103$863 \mathrm{X} 2006000300012$

Rando, T. (2000). Clinical dimensions of anticipatory mourning. Chicago, IL: Research Press.

Rolland, J. S. (1995). Doença crônica e o ciclo de vida familiar [Chronic disease and the family life cycle]. In B. Carter \& M. McGoldrick (Eds.), As mudanças no ciclo de vida familiar - Uma estrutura para a terapia familiar [Changes in the family life cycle - A family therapy framework] (pp. 373-392). Porto Alegre, RS: Artes Médicas.
Santana, J. C. B., Rigueira, A. C. de M., \& Dutra, B. S. (2010). Distanásia: Reflexões sobre até quando prolongar a vida em Unidade de Terapia Intensiva na percepção de enfermeiros [Dysthanasia: Reflections about the extent to which life should be prolonged in ICUs from the standpoint of nurses]. Bioethikos, 4(4), 402-411.

Santos, Q. N. (2013). Estratégia de enfrentamento (coping) da família ante um membro familiar hospitalizado: Uma revisão de literatura brasileira [Coping strategy for families dealing with a hospitalized family member: A review of Brazilian literature]. Mudanças - Psicologia e Saúde, 21(2), 40-47.

Schmidt, B., Gabarra, L. M., \& Gonçalves, J. R. (2011). Intervenção psicológica em terminalidade e morte: Relato de experiência [Psychological intervention in terminal situations and death: An account of the experience]. Paidéia (Ribeirão Preto), 21(50), 423-430. doi:10.1590/ S0103-863X2011000300015

Souza, R. P. (2010). Manual de rotinas de humanização em medicina intensiva - AMIB [Manual of humanization routines in intensive medicine - AMIB]. São Paulo, SP: Atheneu.

Turato, E. R. (2008). Tratado da metodologia da pesquisa clínico-qualitativa: Construção teóricoepistemológica, discussão comparada e aplicação nas áreas da saúde e humanas (3. ed.) [Treatise on the methodology of qualitative clinical research: Theoretical epistemological construction, comparative discussion and application in the areas of healthcare and human sciences ( $3^{\text {rd }}$ ed.)]. Petrópolis, RJ: Vozes.

Walsh, F. (2005). Fortalecendo a resiliência familiar [Strengthening family resilience]. São Paulo, SP: Roca.

Walsh, F., \& McGoldrick, M. (1998). A perda e a família: Uma perspectiva sistêmica [Loss and the family: A systemic perspective]. In F. Walsh \& M. McGoldrick (Eds.), Morte na família: Sobrevivendo às perdas [Death in the family: Surviving the losses] (pp. 27-55). Porto Alegre, RS: ArtMed.

Wiegand, D. L., Grant, M. S., Cheon, J., \& Gergis, M. A. (2013). Family-centered end-of-life care in the ICU. Journal of Gerontological Nursing, 39(8), 60-68.

Recebido: 06/11/2015

$1^{a}$ revisão: $28 / 06 / 2016$

Aceite final: 06/07/2016 